\title{
Children's Resilience Markers: Criterion-based validity evidences
}

\section{Marcadores de Resiliência Infantil: evidências de validade de critério do instrumento}

\author{
Karina da Silva OLIVEIRA ${ }^{1}$ [i] 0000-0002-5301-7012 \\ Tatiana de Cássia NAKANO ${ }^{1}$ (1) 0000-0002-5720-8940 \\ Gisele Maria da SILVA ${ }^{1}$ (i) 0000-0002-3008-1062
}

\begin{abstract}
Although resilience is a relevant construct, there are no Brazilian instruments available to identify the resilient potential in children. Considering this, an instrument called Children's Resilience Markers was developed. The study included 500 children from five different groups, aged 8 to 12. Through ANOVA, it was possible to notice that Children's Resilience Markers was able to differentiate groups that presented higher resilience abilities. Children's Resilience Markers presented good validity evidences. However, other studies must be carried out in order to reach a greater understanding of its psychometric characteristics.
\end{abstract}

Keywords: Psychological assessment; Resilience; Test validity.

\section{Resumo}

Embora resiliência seja um construto relevante, não há instrumentos brasileiros disponíveis para a identificação do potencial resiliente em crianças. Considerando isto, um instrumento chamado Marcadores de Resiliência Infantil foi desenvolvido. Participaram do estudo 500 crianças, com idades entre 8 e 12 anos, as quais compuseram cinco grupos diferentes. Por meio da ANOVA foi possível perceber que o Marcador de Resiliência Infantil foi capaz de diferenciar grupos que apresentaram maiores habilidades resilientes. É possivel afirmar que o Marcador de Resiliência Infantil apresentou boas evidências de validade, contudo outros estudos devem ser conduzidos de modo a alcançar maior compreensão sobre as características psicométricas do instrumento.

Palavras-chave: Avaliação psicológica; Resiliência; Validade do teste.

$\operatorname{rrv}$

${ }^{1}$ Pontifícia Universidade Católica de Campinas, Centro de Ciências da Vida, Programa de Pós-Graduação em Psicologia. Av. John Boyd Dunlop, s/n., Prédio Administrativo CCV, Jardim Ipaussurama, 13060-904, Campinas, SP, Brasil. Correspondência para/Correspondence to: K. S. OLIVEIRA. E-mail: <karina_oliv@yahoo.com.br>.

Support: This study was financed in part by the Coordenação de Aperfeiçoamento de Pessoal de Nível Superior (Capes) (Finance Code 001).

\section{$\sim \mathrm{r}$}

Como citar esse artigo/How to cite this article

Oliveira, K. S., Nakano, T. C., \& Silva, G. M. (2019). Chidren's Resilience Markers: Validity evidence criterion kind. Estudos de Psicologia (Campinas), 36, e180142. http://dx.doi.org/10.1590/1982-0275201936e180142 
Resilience is a widely investigated construct in many different areas (Masten, 2018). In the last five decades, this subject has been investigated by psychologists and different attempts of defining what resilience is have taken place over the years (Brandão, Mahfoud, \& Godoi-Nascimento, 2011; Oliveira \& Nakano, 2018). Although there is little consensus on its best definition, researchers refer to resilience as a psychological phenomenon (Yunes, 2011), indistinctly found in individuals and in their communities (Masten, 2014, 2018). Also, the resilient process aims to present a positive adaptation or even a good outcome (Reppold, Mayer, Almeida, \& Hutz, 2012) in face of real or perceived adversities (Castillo, Castillo-López, López-Sánchez, \& Dias, 2016). Likewise, different authors defend resilience as a developmental characteristic, mostly because its process can be improved through previous experience and mature growth, relying on both personal and social resources (Castillo et al., 2016; Fontes, 2010; Masten, 2018).

Therefore, according to the literature, resilience is a complex construct involving intricate interactions of personal attributes and environmental circumstances (Prince-Embury, 2010). Thus, measuring it is also a multifaceted activity that has been part of different studies all through these decades (Harihana \& Rana, 2017). As Bennetti and Crepaldi (2012) point out, researchers usually assessed resilience quantifying protective and risk factors. Complementing this idea, Masten $(2001,2018)$ says that, after realizing that resilience was more than the balance between protective and risk factors, resilience assessments began encompassing the measure of negative events and adaptive outcomes. Most recently, influenced by Positive Psychology (Polleto, 2006), resilience assessments also came to include the measurement of personal and context resources involved in the process of coping with adversities (Oliveira \& Nakano, 2018).

Even though it is important to evaluate one's resilient potential, Infante (2007) and Masten (2018) consider the kinds of conclusions a resilience assessment might reach. For these authors, high scores, or even the identification of high levels of resilience, do not mean that someone should be considered invulnerable or that these results are settled and permanent. As Masten $(2001,2018)$ points out, there are many different elements involved in an adaptive outcome, that may or may not contribute to the development of resilient processes, such as environmental, individual and subjective issues. These elements must be considered when assessing this potential.

There are some resilience measures worldwide (Masten, 2018; Prince-Embury, 2010). However, in Brazil there are no available measures for this matter at Sistema de Avaliação de Testes Psicológicos [Psychological Testing Evaluation System], so most resilience assessments are qualitative (Reppold et al., 2012). Additionally, when investigators choose an objective measure, they commonly assess constructs related to resilience and not resilience itself (Oliveira \& Nakano, 2018). Building on this, Reppold et al. (2012) also say that there are validity problems within resilience tests since, according to these authors, the items presented on some measures are most likely to be social adjustment ones, rather than resilience items.

Hence, developing appropriated measures and searching for their validity evidences are important matters of work for researchers whose focus is on the cited gap (Oliveira \& Nakano, 2018; Prince-Embury, 2010; Reppold et al., 2012). According to the American Educational Research Association, the American Psychological Association, and the National Council of Measurement in Education (2014), there are many different validity evidences that must be investigated in the process of developing a psychological measure. Among the different kinds of validity evidences, those based on the relations with other variables should be highlighted. They comprise two different kinds: the criterion-based and the divergent (Freitas \& Damásio, 2017). To the purpose of this research, we will build on the criterion-based. This kind of validity evidence enables the identification of people belonging to differentiated groups through theoretical-, logical-, and empirical-based criteria, who will or will not meet the selected criteria (Nunes \& Primi, 2010).

One of the challenges of a criterion-based validity study is selecting the best standards (Souza, Alexandre, 2 \& Guirardello, 2017), especially in investigations involving resilience. As previously mentioned, there are 
many different definitions and comprehensions of this construct (Brandão et al., 2011; Castillo et al., 2016; Harihana \& Rana, 2017) and therefore, researchers have not reached a common language (Masten, 2018). Likewise, the selected criteria could not be the scores from another test measure, since there is none available in Brazil (Oliveira \& Nakano, 2018). Thus, to select a criterion for this matter, one needs to comprehend the contexts in which resilience is being developed in advance.

The Brazilian Law of Guidelines and Bases for Education (Presidência da República, 1996) defends that non-governmental organizations are the appropriate context to further develop cognitive and social skills, offering a safe environment in which children and teenagers can have enriching experiences, promoting resilient characteristics and abilities such as: positive affections, altruistic attitudes, autonomy, optimism, self-efficacy, effective coping strategies, and emotional control in face of criticism and adversities (Castillo et al., 2016; Prince-Embury, 2013; Zolkoski \& Bullock, 2012). Therefore, it is possible to say that children and teenagers who attend non-governmental organizations are exposed to a more protective context, potentially leading them towards the development of resilience and other abilities (Matias, 2009).

Sports are also a fruitful context to develop resilience skills (Cevada et al., 2012), offering many possibilities of coping with challenging situations, increasing self-discipline, managing complex emotions, and being assertive, for instance (Castillo et al., 2016; Prince-Embury, 2013; Zolkoski \& Bullock, 2012). However, sports can also be stressful contexts, especially for high-performance athletes (Hill, Hartigh, Meijer, Jonge, \& Van Yperen, 2018), as those athletes deal with rigorous training conditions, long competitions, high demands and expectations, and a continuous search for meeting personal and collective goals (Pedro \& Veloso, 2018). Thus, such athletes are more likely to rely on their resilience abilities to face sports challenges (Secades et al., 2017).

In face of the absence of proper measures to assess resilience in Brazil (Oliveira \& Nakano, 2018; Reppold et al., 2012) and considering the importance of studies that aim to understand psychometric properties (American Educational Research Association et al., 2014), this study's intentions are to investigate the criterion-based validity for a measure developed to assess children between 8 and 12 years old's resilience, called Marcadores de Resiliência Infantil [Children's Resilience Markers - CRM].

\section{Method}

\section{Participants}

The non-probabilistic convenient sample included 500 children (girls $=223$, boys $=277$ ) aged 8 to 12 years old $(M=9.86$; $S D=1.28)$, from the Metropolitan Region of São Paulo (MRSP) and the Metropolitan Region of Campinas (MRC). The participants attended the $2^{\text {nd }}(n=14), 3^{\text {rd }}(n=123), 4^{\text {th }}(n=105), 5^{\text {th }}(n=128)$, $6^{\text {th }}(n=116)$, and $7^{\text {th }}$ grades $(n=14)$ of elementary school. Based on the participants' answer sheets, 5 different groups were identified:

G1: 136 students from a public school in a poor community in the MRC;

G2: 156 students from a public school in a rural area in the MRC;

G3: 48 students from a bilingual private school in the MRC;

G4: 121 students from different public schools in the MRSP, who attended a non-governmental organization after school, and

G5: 39 athletes from youth categories of different soccer teams of the MRSP.

Further details about these participants are in Table 1. 
Table 1

Detailed information about the groups

\begin{tabular}{|c|c|c|c|c|c|c|c|c|c|c|c|c|c|}
\hline \multirow{3}{*}{\multicolumn{2}{|c|}{ Characteristics }} & \multicolumn{10}{|c|}{ Groups } & \multirow{2}{*}{\multicolumn{2}{|c|}{$\begin{array}{c}\text { Total } \\
(N=500)\end{array}$}} \\
\hline & & \multicolumn{2}{|c|}{$\begin{array}{c}1 \\
(n=136)\end{array}$} & \multicolumn{2}{|c|}{$\begin{array}{c}2 \\
(n=156)\end{array}$} & \multicolumn{2}{|c|}{$\begin{array}{c}3 \\
(n=48)\end{array}$} & \multicolumn{2}{|c|}{$\begin{array}{c}4 \\
(n=121)\end{array}$} & \multicolumn{2}{|c|}{$\begin{array}{c}5 \\
(n=39)\end{array}$} & & \\
\hline & & $\mathrm{F}$ & $\%$ & $\mathrm{~F}$ & $\%$ & $\mathrm{~F}$ & $\%$ & $\mathrm{~F}$ & $\%$ & $\mathrm{~F}$ & $\%$ & $\mathrm{~F}$ & $\%$ \\
\hline \multirow[t]{3}{*}{ Gender } & Girls & 67 & 49.26 & 74 & 47.44 & 25 & 52.08 & 57 & 47.11 & 0 & 0.00 & 223 & 44.60 \\
\hline & Boys & 69 & 50.74 & 82 & 52.56 & 23 & 47.92 & 64 & 52.89 & 39 & 100.00 & 277 & 55.40 \\
\hline & Total & 136 & 100.00 & 156 & 100.00 & 48 & 100.00 & 121 & 100.00 & 39 & 100.00 & 500 & 100.00 \\
\hline \multirow[t]{6}{*}{ Age } & 8 & 31 & 22.79 & 14 & 8.97 & 19 & 39.58 & 25 & 20.66 & 0 & 0.00 & 89 & 17.80 \\
\hline & 9 & 34 & 25.00 & 43 & 27.56 & 11 & 22.92 & 31 & 25.62 & 1 & 2.57 & 120 & 24.00 \\
\hline & 10 & 32 & 23.53 & 35 & 22.44 & 13 & 27.08 & 33 & 27.27 & 6 & 15.38 & 119 & 23.80 \\
\hline & 11 & 27 & 19.85 & 37 & 23.72 & 5 & 10.42 & 25 & 20.66 & 18 & 46.15 & 112 & 22.40 \\
\hline & 12 & 12 & 8.83 & 27 & 17.31 & 0 & 0.00 & 7 & 5.79 & 14 & 35.90 & 60 & 12.00 \\
\hline & Total & 136 & 100.00 & 156 & 100.00 & 48 & 100.00 & 121 & 100.00 & 39 & 100.00 & 500 & 100.00 \\
\hline \multirow[t]{7}{*}{ Grades } & $2^{\text {nd }}$ & 0 & 0.00 & 0 & 0.00 & 14 & 29.16 & 0 & 0.00 & 0 & 0.00 & 14 & 2.80 \\
\hline & $3^{\text {rd }}$ & 35 & 25.74 & 44 & 28.21 & 11 & 22.92 & 33 & 27.27 & 0 & 0.00 & 123 & 24.60 \\
\hline & $4^{\text {th }}$ & 37 & 27.21 & 32 & 20.51 & 8 & 16.67 & 26 & 21.49 & 2 & 5.12 & 105 & 21.00 \\
\hline & $5^{\text {th }}$ & 27 & 19.84 & 39 & 25.00 & 15 & 31.25 & 36 & 29.75 & 11 & 28.21 & 128 & 25.60 \\
\hline & $6^{\text {th }}$ & 37 & 27.21 & 41 & 26.28 & 0 & 0.00 & 23 & 19.01 & 15 & 38.46 & 116 & 23.20 \\
\hline & $7^{\text {th }}$ & 0 & 0.00 & 0 & 0.00 & 0 & 0.00 & 3 & 2.48 & 11 & 28.21 & 14 & 2.80 \\
\hline & Total & 136 & 100.00 & 156 & 100.00 & 48 & 100.00 & 121 & 100.00 & 39 & 100.00 & 500 & 100.00 \\
\hline
\end{tabular}

\section{Instruments}

Children's Resilience Markers (CRM) is a psychological measure which aims to assess resilient characteristics in Brazilian children aged 8 to 12 years old. The measure's development departed from the theoretical model in Castillo et al. (2016). For these authors, resilience is an intricated process that involves six fundamental elements: vulnerability, coping, emotional intelligence, subjective well-being, control locus, and ability. CRM has 22 illustrated items presented as short stories. The main characters are Nina and Nino. They are introduced as children of the same age as the test-takers. In each item one of these main characters has to deal with a challenging situation. The test-taker is invited to choose one of three options, providing an outcome based on what he or she would do if they were in the same situation as Nina or Nino.

The points for each item vary from 0 to 2 . The options are presented randomly so that a pattern cannot be established during the execution of the task. The maximum score is 44 points. The vulnerability factor has 4 items; therefore, the maximum score is 8 points. The coping factor has 3 items ( 6 points), the emotional intelligence factor has 4 items (8 points), the subjective well-being factor has 3 items (6 points), the control locus factor has 5 items (10 points), and the last factor, ability, has 3 items ( 6 points).

This measure is still being developed, so different validity investigations were conducted to further understand the CRM's psychometric properties. Initially, its content validity was investigated. Sixteen specialists evaluated the item's theoretical adequacy and good content-based validity evidence was found among the items. Also, these specialists were responsible for establishing the points for each item's options, resulting in the development of a punctuation system. After that, the CRM's adequacy was addressed through pilot studies divided into two moments. In the first moment, two groups of 5 children, one with children aged 8 and 9 years old and the other 11 and 12 years old, were invited to evaluate the CRM's items and its answer sheet. In the second moment, two groups with children of the same age were invited to evaluate the adequacy of the CRM material. These actions showed good results.

Afterwards, a study of evidences based on internal structure and reliability was conducted. The Confirmatory

4 Factor Analysis results showed that a Bi-factor model explained the distribution of items better, confirming 
the existence of six factors and a general factor. The six factors are consistent with the six fundamental elements proposed by the theoretical model (Castillo et al., 2016) that supports the development of the CRM. Reliability was investigated through the alpha's coefficient and the values ranged from 0.381 to 0.866 . Moreover, the CRM's validity evidence based on the relations with other variables - divergent kind, was investigated comparing its scores to Escala de Stress Infantil [Child Stress Scale - CSS]. The results pointed to a negative correlation between those measures, ranging from -0.219 to 0.052 . All these studies are part of a doctoral dissertation and some of them were already submitted to scientific journals and are currently waiting evaluation.

\section{Procedures}

This study was approved by the ethics committee of Pontifícia Universidade Católica de Campinas [PUC-Campinas, Pontifical Catholic University of Campinas] (CAAE 66606517.5.0000.5481). After receiving all the signed consent forms, we invited the participants to execute the task in an adequate place provided by the institutions that hosted the research. Data was gathered collectively using a printed version of the CRM. A database was created containing the points for each item, the total punctuation for each factor, and the CRM's grand total.

The data was analyzed with the Statistical Package for the Social Sciences v.22, and the following analyses were conducted: Mean (M), Standard Deviation (SD), Univariate Analyses (ANOVA), Post hoc - Tukey's Honestly Significant Difference (HSD) and the effect size through Cohen's coefficient ( $d$ ). Therefore, as Espírito-Santo and Daniel (2015) advised: values lower than 0.19 were interpreted as indicators of "insignificant effect"; values ranging from 0.20 to 0.49 , "small effect"; values ranging from 0.50 to 0.79 , "medium effect"; values ranging from 0.80 to 1.29 , "large effect"; and "very large effect" for values greater than 1.30.

\section{Results}

The first round of analyses involved the mean and standard deviation for the five groups, considering the six CRM factors and its grand total. Information is presented in Table 2. The results indicated that G1 participants had the lower means compared to other groups for the factors 4 - Subjective well-being and 6 - Ability. Likewise, G5 participants also had the lower means for the factors 1 - Vulnerability, 2 - Coping, 3 - Emotional Intelligence, and 5 - Control locus, as well as for the CRM's grand total. Otherwise, higher means were found for: $\mathrm{G} 2$, factor 2 - Coping and for the CRM's grand total; G3, factors 3 - Emotional Intelligence and 6 - Ability; G4, factors 1 - Vulnerability and 5 - Control locus; and G5, factor 5 - Subjective well-being.

The ANOVA results indicated a highly significant influence of the group variable for all the CRM factors and the grand total. This data is presented in Table 2. Given these results and in order to explore the differences between the different sets of means, the Post hoc Tukey's DHS was performed together with size effect analyzes (Cohen's d). The results can be seen in Table 3. Considering factor 1 - Vulnerability, only one difference among the means was significant, involving groups 1 and 4 , and favoring the last one, but with a small size effect $(d=0.38 ; p \leq 0.001)$.

Regarding factor 2 - Coping, several significant differences were found among the five groups. In three cases the size effect was considered medium: for $G 1$ and $G 2$, favoring $G 2(d=0.50, p \leq 0.001)$; for $\mathrm{G} 1$ and $\mathrm{G} 5$, favoring $\mathrm{G} 1$ ( $d=0.55 ; p \leq 0.001)$; and for $\mathrm{G} 2$ and $\mathrm{G} 3$, favoring $\mathrm{G} 2(d=0.58 ; p \leq 0.001)$. Two other comparisons were significant and considered a large size effect, with $\mathrm{G} 2$ and $\mathrm{G} 5$, favoring the first group $(d=1.17 ; p \leq 0.001)$, and $\mathrm{G} 4$ and $\mathrm{G} 5$, favoring $\mathrm{G} 4(d=0.91 ; p \leq 0.001)$. For factor 3 - Emotional intelligence, significant differences for $G 1$ compared to $G 2$, and $G 1$ to $G 3$ were observed. In these comparisons, the means 
Table 2

Means (M), Standard Deviation (SD) and Univariate Analysis (ANOVA)

\begin{tabular}{ccccccccc}
\hline \multirow{2}{*}{ Groups } & & \multicolumn{9}{c}{ CRM's factors and total } \\
\cline { 2 - 8 } & & Factor 1 & Factor 2 & Factor 3 & Factor 4 & Factor 5 & Factor 6 & Total \\
\hline G1 & $M$ & 5.09 & 3.95 & 5.74 & 4.10 & 7.32 & 3.90 & 30.10 \\
$(n=136)$ & $S D$ & 2.03 & 1.76 & 1.94 & 1.51 & 2.43 & 1.54 & 8.33 \\
G2 & $M$ & 5.62 & 4.72 & 6.75 & 4.63 & 8.13 & 4.63 & 34.48 \\
$(n=156)$ & $S D$ & 1.80 & 1.29 & 1.47 & 1.12 & 2.17 & 1.32 & 6.31 \\
G3 & $M$ & 5.19 & 3.75 & 6.92 & 4.31 & 7.79 & 4.94 & 32.90 \\
$(n=48)$ & $S D$ & 1.88 & 1.99 & 1.16 & 1.25 & 3.04 & 1.29 & 8.43 \\
G4 & $M$ & 5.83 & 4.45 & 6.28 & 4.65 & 8.30 & 4.49 & 34.00 \\
$(n=121)$ & $S D$ & 1.84 & 1.65 & 1.91 & 1.33 & 2.29 & 1.51 & 8.41 \\
G5 & $M$ & 5.03 & 2.87 & 4.92 & 5.13 & 5.82 & 4.13 & 27.90 \\
$(n=39)$ & $S D$ & 1.91 & 1.82 & 1.76 & 0.65 & 3.06 & 1.41 & 7.54 \\
\hline Total & $M$ & 5.44 & 4.21 & 6.24 & 4.50 & 7.74 & 4.39 & 32.51 \\
$(N=500)$ & $S D$ & 1.91 & 1.71 & 1.81 & 1.30 & 2.52 & 1.47 & 8.01 \\
\hline F & & $3,464 *$ & $12,769 *$ & $13,807 *$ & $6,829 *$ & $9,584 *$ & $7,149 *$ & $10,460 *$ \\
\hline
\end{tabular}

Note: * $p \leq 0,01$. Factor 1: Vulnerability; Factor 2: Coping; Factor 3: Emotional Intelligence; Factor 4: Subjective well-being; Factor 5: Control Locus; Factor 6: Ability. CRM: Children's Resilience Markers.

Table 3

Post Hoc Tukey's DHS

\begin{tabular}{|c|c|c|c|c|c|c|}
\hline CRM & Groups & 1 & 2 & 3 & 4 & 5 \\
\hline \multirow{5}{*}{ Vulnerability } & 1 & - & - & - & -0.738 & - \\
\hline & 2 & - & - & - & - & - \\
\hline & 3 & - & - & - & - & - \\
\hline & 4 & 0.738 & - & - & - & - \\
\hline & 5 & - & - & - & - & - \\
\hline \multirow{5}{*}{ Coping } & 1 & - & -0.769 & - & - & 1.077 \\
\hline & 2 & 0.769 & - & 0.968 & - & 1.846 \\
\hline & 3 & - & -0.968 & - & - & - \\
\hline & 4 & - & - & - & - & 1.583 \\
\hline & 5 & -1.077 & -1.846 & - & -1.583 & - \\
\hline \multirow{5}{*}{$\begin{array}{l}\text { Emotional } \\
\text { intelligence }\end{array}$} & 1 & - & -1.007 & -1.174 & - & - \\
\hline & 2 & 1.007 & - & - & - & 1.827 \\
\hline & 3 & 1.174 & - & - & - & 1.994 \\
\hline & 4 & - & - & - & - & 1.358 \\
\hline & 5 & - & -1.827 & -1.994 & -1.358 & - \\
\hline \multirow{5}{*}{$\begin{array}{l}\text { Subjective } \\
\text { well-being }\end{array}$} & 1 & - & -0.533 & - & -0.557 & -1.033 \\
\hline & 2 & 0.533 & - & - & - & - \\
\hline & 3 & - & - & - & - & -0.816 \\
\hline & 4 & 0.557 & - & - & - & - \\
\hline & 5 & 1.033 & - & 0.816 & - & - \\
\hline \multirow{5}{*}{ Control locus } & 1 & - & -0.811 & - & -0.974 & 1.503 \\
\hline & 2 & 0.811 & - & - & - & 2.314 \\
\hline & 3 & - & - & - & - & 1.971 \\
\hline & 4 & 0.974 & - & - & - & 2.477 \\
\hline & 5 & -1.503 & -2.314 & -1.971 & -2.477 & - \\
\hline \multirow{5}{*}{ Ability } & 1 & - & -0.724 & -1.033 & -0.583 & - \\
\hline & 2 & 0.724 & - & - & - & - \\
\hline & 3 & 1.033 & - & - & - & - \\
\hline & 4 & 0.583 & - & - & - & - \\
\hline & 5 & - & - & - & - & - \\
\hline \multirow{5}{*}{ Total } & 1 & - & -4.378 & - & -3.897 & - \\
\hline & 2 & 4.378 & - & - & - & 6.583 \\
\hline & 3 & - & - & - & - & 4.998 \\
\hline & 4 & 3.897 & - & - & - & 6.103 \\
\hline & 5 & - & -6.583 & -4.998 & -6.103 & - \\
\hline
\end{tabular}

6 Note: $p \leq 0,05$ for the presented values. CRM: Children's Resilience Markers; DHS: Honestly Significant Difference. 
were significantly higher for $\mathrm{G} 2(d=0.59 ; p \leq 0.001)$ and $\mathrm{G} 3(d=0.74 ; p \leq 0.001)$, with mean size effects. The differences between the means of $\mathrm{G} 5$ and $\mathrm{G} 2, \mathrm{G} 5$ and $\mathrm{G} 3, \mathrm{G} 5$ and $\mathrm{G} 4$, were also significant, indicating higher means for $\mathrm{G} 2, \mathrm{G} 3$, and $\mathrm{G} 4$. The size effects were larger for $\mathrm{G} 5$ and $\mathrm{G} 2$ ( $d=1.13, p \leq 0.001$ ), medium for $\mathrm{G} 5$ and $\mathrm{G} 3(d=0.67, p \leq 0.001)$, and also medium for $\mathrm{G} 5$ and $\mathrm{G} 4(d=0.74, p \leq 0.001)$.

Concerning Factor 4 - Subjective well-being, significant differences were found between G1 and G2, G4 and G5. The higher means were identified for Groups 2, 4, and 5 as compared to Group 1, with size effects considered small for the interaction between 1 and $2(d=0.40, p \leq 0.001), 1$ and $4(d=0.39$; $p \leq 0.001)$, and large for the interaction between 1 and $5(d=0.89, p \leq 0.001)$. There were also significant differences in the comparison between $\mathrm{G} 5$ and $\mathrm{G} 3, \mathrm{G} 5$ and $\mathrm{G} 4$, such differences favoring Group 5 . The size effects were considered large for the comparison between $\mathrm{G} 5$ and $\mathrm{G} 3(d=0.82, p \leq 0.001)$ and small for the interaction between $\mathrm{G} 5$ and $\mathrm{G} 4(d=0.46, p \leq 0.03)$.

The fifth factor - Control locus, presented the highest number of significative interactions among the five groups. When $\mathrm{G} 1$ was compared to $\mathrm{G} 2$ and $\mathrm{G} 4$, it had lower means than the other two groups. The size effect was considered small for both interactions: $\mathrm{G} 1$ and $\mathrm{G} 2(d=0.35 ; p \leq 0.001), \mathrm{G} 1$ and $\mathrm{G} 4(d=0.42$; $p \leq 0.001)$. Mean size effects were found between groups $\mathrm{G} 1$ and $\mathrm{G} 5(d=0.54, p \leq 0.001)$ and between G5 and G3 ( $d=0.65, p \leq 0.001)$, and large size effects appeared when comparing G5 and G2 ( $d=0.87$, $p \leq 0.001)$, as well as $\mathrm{G} 5$ and $\mathrm{G} 4(d=0.92, p \leq 0.001)$.

For factor 6 - Ability, there were significant mean differences between $\mathrm{G} 1$ and $\mathrm{G} 2(d=0.51 ; p \leq 0.001)$, $\mathrm{G} 1$ and $\mathrm{G} 3(d=0.73 ; p \leq 0.001)$, and $\mathrm{G} 1$ and $\mathrm{G} 4(d=0.39 ; p \leq 0.001)$, favoring $\mathrm{G} 2, \mathrm{G} 3$, and $\mathrm{G} 4$. At last, considering the CRM's grand total, significant differences were observed between $\mathrm{G} 1$ and $\mathrm{G} 2(d=0.59$; $p \leq 0.001), \mathrm{G} 1$ and $\mathrm{G} 4(d=0.47 ; p \leq 0.001)$. Also, significant differences were found between $\mathrm{G} 5$ and $\mathrm{G} 2$ $(d=1.15 ; p \leq 0.001), \mathrm{G} 5$ and $\mathrm{G} 3(d=1.07 ; p \leq 0.001)$, and $\mathrm{G} 5$ and $\mathrm{G} 4(d=1.11 ; p \leq 0.001)$.

\section{Discussion}

Resilience is currently a controversial and important construct. In the course of their histories, both the concept and the assessment strategies were refined to the point that, even though there is little consensus on the best definition of resilience (Brandão et al., 2011; Oliveira \& Nakano, 2018), different authors defend that its intricated multifaceted psychological process is involved in a good outcome or even positive adaptation facing adversities (Castillo et al., 2016; Fontes, 2010; Harihana \& Rana, 2017; Masten, 2014, 2018; Prince-Embury, 2010; Reppold et al., 2012; Yunes, 2011).

Considering its relevance and the gaps in the Brazilian scientific scenario regarding its assessment specially for kids, a form of measurement was developed. Taking the guidelines of the American Educational Research Association et al. (2014), different studies were conducted to comprehend the psychometric properties of the Children's Resilience Markers. This paper aims to describe a study in which criterion-based validity evidences were investigated. Establishing the best criteria for this matter required theoretical comprehension of which contexts should be taken as resilience promoters. This strategy was chosen due to the lack of measures of children's resilience assessments in Brazil to compare with the CRM's results (Oliveira \& Nakano, 2018).

Therefore, based on the specialized literature (Presidência da República, 1996; Cevada et al., 2012; Matias, 2009), non-governmental organizations and sports contexts were considered spaces with good potential to develop resilient characteristics. However, sports contexts are not favorable to the development of resilience. As Hill et al. (2018), Pedro and Veloso (2018), and Secades et al. (2017) point out, high-performance athletes have a stressful relationship with sports, so it is most likely that these athletes rely on their resilience skills rather than develop them in that context. Thus, we expected the participants of non-governmental organizations to present higher means compared to the other four groups. Moreover, we expected participants 
of soccer teams' youth categories to present medium or low means compared to the other groups, since these participants were also high-performance athletes, at times from an early age.

The results met those expectations for high-performance athletes, as they had the lower means for the factors 1-vulnerability, 2-coping, 3-emotional intelligence, 5-control locus, and for the CRM's grand total. These participants presented higher means for factor 4-subjective well-being. As described in the model's definition (Castillo et al., 2016), this fundamental element can be recognized by the level of positive evaluation and satisfaction with one's life. This group possibly felt important validation and personal realization for being chosen to play for big important soccer teams and thus, their means were higher than the ones from other groups.

Another relevant aspect of group 5's results is that, compared to other groups, the mean was significantly reduced (with the exception of factor 4-subjective well-being). This is probably related to high-performance athletes dealing with a stressful context with high demands and expectations, as the literature defends (Hill et al., 2018; Pedro \& Veloso, 2018; Secades et al., 2017). Henceforth, the CRM seemed able to identify and even differentiate this group's necessity.

Participants of non-governmental organizations (Group 2) had higher means for factor 2-coping and for the CRM's grand total. Investigating the interactions among group 2 and the other groups (Table 3), the mean differences were always significant and favoring group 2, even though this group did not have higher means in the other factors. The results also met the expectations of group 2's performance, and the measurement was able to identify this ability in those participants.

Group 1 (students from a poor community) showed significant mean differences when compared to other groups, differences that favored the other groups except for factors 2-coping and 5-control locus. Thus, the CRM was able to differentiate participants for different levels of resilience based on their context. However, it is important to note that this is an initial study and additional investigations must be conducted to further comprehend the CRM's psychometric properties.

\section{Conclusion}

Measuring resilience is a complex and challenging activity (Prince-Embury, 2010). Considering the current century's challenges for individuals (Masten, 2001, 2018), it is important to understand one's potential to cope with adversities and which characteristics must be developed and strengthened (Oliveira \& Nakano, 2018) for that purpose. Facing a gap in Brazilian forms of measurement of children's resilience, different studies were part of the process of developing and investigating the psychometric properties of Children's Resilience Markers.

Even though the results met our expectations, we should also raise the study's difficulties and vulnerabilities. The main challenge was to find good criteria to identify people belonging to differentiated groups (Nunes \& Primi, 2010). For the present study, the groups' characteristics were chosen as criteria. However, other characteristics could have been selected, such as: previous diagnosis of psychopathologies, previous difficult experiences, among others. Thus, other studies must be carried out with different criteria to better evaluate the CRM's ability to differentiate groups.

Another challenge was to reach the participants, specially those from private schools and athletes, which were the groups with fewer participants. Hence, the analyzed data was not equivalent in terms of number of participants. Despite these difficulties, the results are promising and the instrument presented 8 good potential to assess children's resilience. 


\section{Acknowledgements}

The authors also thank André Felipe R. G. B. de Oliveira for the valuable help with the English review.

\section{Contributors}

K. S. OLIVEIRA was responsible for the conception of this study, data collection, data analysis, results' interpretation and for the paper's writing. T. C. NAKANO and G. M. SILVA contributed to the discussion, revision and approval of the final version of the manuscript.

\section{References}

American Educational Research Association, American Psychological Association, \& National Council of Measurement in Education. (2014). Standards for educational and psychological testing. Washington, DC: Author.

Benetti, I. C., \& Crepaldi, M. A. (2012). Resiliência revisitada: uma abordagem reflexiva para principiantes no assunto. Revista Eletrónica de Investigación y Docencia, 7(1), 7-30. Recuperado em novembro 17, 2018, de http://www.ujaen. es/revista/reid/revista/n7/RevistaNum7REID.pdf

Brandão, J. M., Mahfoud, M., \& Gianordoli-Nasciento, I. F. (2011). A construção do conceito de resiliência em psicologia: discutindo as origens. Paidéia, 21(49), 263-271. http://dx.doi.org/10.1590/\$0103-863X2011000200014

Castillo, J. A. G., Castillo-López, A. G., López-Sánchez, C., \& Dias, P. C. (2016). Conceptualización teórica de la resiliencia psicosocial y su relación con la salud. Health and Addictions, 16(1), 59-68. http://dx.doi.org/10.21134/haaj.v16i1.263

Cevada, T., Cerqueira, L. S., Moraes, H. S., Santos, T. M., Pompeu, F. A. M. S., \& Deslandes, A. C. (2012). Relação entre esporte, resiliência, qualidade de vida e ansiedade. Revista de Psiquiatria Clínica, 39(3), 85-89. http://dx.doi.org/10.1590/ S0101-60832012000300003

Espírito-Santo, H., \& Daniel, F. (2015). Calcular e apresentar tamanhos do efeito em trabalhos científicos (1): as limitações do $p<0 / 05$ na análise de diferenças de média de dois grupos. Revista Portuguesa de Investigação Comportamental e Social, 1(1), 3-16. http://dx.doi.org/10.7342/ismt.rpics.2015.1.1.14

Fontes, A. P. (2010). Resiliência, segundo o paradigma do desenvolvimento ao longo da vida (life-span). Kairós, 7(1), 8-20. Recuperado em novembro 17, 2018 de https://revistas.pucsp.br/index.php/kairos/article/view/3917

Freitas, C. P. P., \& Damásio, B. F. (2017). Evidências de validade com base nas relações com medidas externas: conceituação e problematização. In B. D. Damásio, \& J. C. Borsa (Orgs.), Manual de desenvolvimento de instrumentos psicológicos (pp.101-117). São Paulo: Vetor.

Hill, Y., Hartigh, R. J. R., Meijer, R. R., Jonge, P., \& Van Yperen, N. W. (2018). Resilience in sports from a dynamical perspective. Sport, Exercise and Performance Psychology, 7(4), 333-341. http://dx.doi.org/10.1037/spy0000118

Harihana, M., \& Rana, S. (2017). Conceptual complexity of resilience: Synergy approach to measurement. In U. Kumar (Ed.), The Routledge International Handbook of Psychosocial Resilience (pp.101-118). New York: Routledge.

Infante, F. (2007). A resiliência como processo: uma revisão da literatura recente. In A. Melillo \& E. N. S. Ojeda (Orgs.), Resiliência: descobrindo as próprias fortalezas (pp. 23-38). Porto Alegre: Artmed.

Masten, A. S. (2001). Ordinary magic: Resilience processes in development. American Psychologist, 56(3), 227-238. http://dx.doi.org/10.1037/0003-066X.56.3.227

Masten, A. S. (2018). Resiliecy theory and research on children and families: Past, present, and promise. Journal of Family Theory \& Review, 10(1), 12- 31. http://dx.doi.org/10.1111/jttr.12255

Matias, N. C. F. (2009). Escolas de tempo integral e atividades extracurriculares: universos à espera da psicologia brasileira. Psicologia em Revista, 15(3), 120-139. http://dx.doi.org/10.5752/P.1678-9563.2009v15n3p120

Nunes, C. H. S. S. \& Primi, R. (2010). Aspectos técnicos e conceituais da ficha de avaliação dos testes psicológicos. In Conselho Federal de Psicologia (CFP). Avaliação Psicológica: diretrizes na regulamentação da profissão (pp. 101-128). Brasilia: CFP.

Oliveira, K. S., \& Nakano, T. C. (2018). Avaliação da resiliência em psicologia: revisão do cenário científico brasileiro. Psicologia em Pesquisa, 12(1), 1-11. http://dx.doi.org/10.5327/Z1982-1247201500020003 
Pedro, S. D., \& Veloso, S. (2018). Explorando la resiliencia em deporte. Apoyo del entrenador a la autonomía y compromiso del atleta: una contribuicíon a la literatura. Cuadernos de Psicología del Deporte, 18(1), 151-160. http://dx.doi. org/10.4321/S1578-84232014000300010

Poletto, M. (2006). Uma breve reflexão crítica sobre psicologia positiva e resiliência. Psicologia Escolar e Educacional, 10(1), 137-140. http://dx.doi.org/10.1590/S1413-85572006000100014

Presidência da República (Brasil). (1996). Lei n 9.394, de 20 de dezembro de 1996. Estabelece as diretrizes e bases da educação nacional. Diário Oficial da União, 134(248). Recuperado em novembro 17, 2018, de http://www.planalto. gov.br/ccivil_03/leis/19394.htm

Prince-Embury, S. (2010). Introduction to special issue: assessing resiliency in children and adolescents. Journal of Psychoeducational Assessment, 28(4), 287-290. http://dx.doi.org/10.1177/0734282910366830

Prince-Embury, S. (2013). Translating resilience theory for assessment and application with children, adolescents, and adults: Conceptual issues. In S. Prince-Embury \& D. H. Saklofske (Orgs.), Resilience in children, adolescents, and adults: Translating research into practice (pp. 9-16). New York: Springer.

Reppold, C. T., Mayer, J. C., Almeida, L. S., \& Hutz, C. S. (2012). Avaliação da resiliência: controvérsia em torno do uso de escalas. Psicologia: Reflexão e Crítica, 25(2), 248-255. http://dx.doi.org/10.1590/S0102-79722012000200006

Secades, X. G., Molinero, O., Barquín, R. R., Salguero, A., De La Vega, R., \& Márquez, S. (2017). Resiliencia y recuperacíonestrés en deportistas de competición. Cuadernos de Psicología del Deporte, 17(2), 73-80.

Souza, A. C., Alexandre, N. M. C., \& Guirardello, E. B. (2017). Propriedades psicométricas na avaliação de instrumentos: avaliação da confiabilidade e da validade. Epidemiologia e Serviços de Saúde, 26(3), 649-659. http://dx.doi.org/10.5123/ S1679-49742017000300022

Yunes, M. A. M. (2011). Psicologia positiva e resiliência: foco no indivíduo e na família. In D. D. Dell'Aglio, S. H. Koller, \& M. A. M. Yunes (Orgs.), Resiliência e psicologia positiva: interfaces do risco a proteção (pp. 45-68). São Paulo: Casa do Psicólogo.

Zolkoski, S. M., \& Bullock, L. M. (2012). Resilience in children and youth: A review. Children and Youth Services Review, 34(1), 2295-2303. http://dx.doi.org/10.1016/j.childyouth.2012.08.009

Received: November 26, 2018

Approved: April 4, 2019 